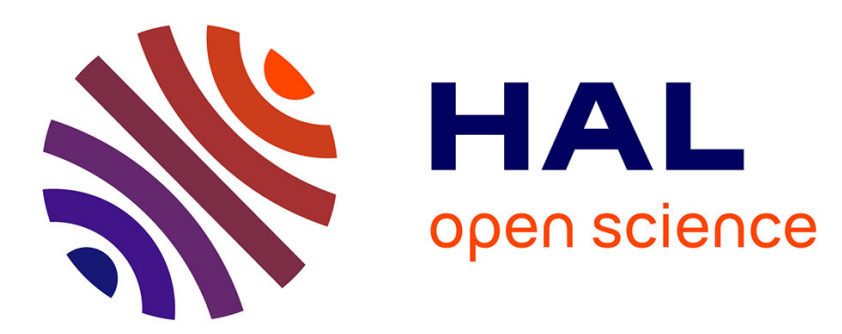

\title{
Dissolved uranium, vanadium and molybdenum behaviours during contrasting freshwater discharges in the Gironde Estuary (SW France)
}

Emilie Strady, Gérard Blanc, Jörg Schäfer, Alexandra Coynel, Aymeric Dabrin

\section{- To cite this version:}

Emilie Strady, Gérard Blanc, Jörg Schäfer, Alexandra Coynel, Aymeric Dabrin. Dissolved uranium, vanadium and molybdenum behaviours during contrasting freshwater discharges in the Gironde Estuary (SW France). Estuarine, Coastal and Shelf Science, 2009, 83 (4), pp.550-560. 10.1016/j.ecss.2009.05.006 . hal-02357369

\section{HAL Id: hal-02357369 \\ https://hal.science/hal-02357369}

Submitted on 14 Nov 2019

HAL is a multi-disciplinary open access archive for the deposit and dissemination of scientific research documents, whether they are published or not. The documents may come from teaching and research institutions in France or abroad, or from public or private research centers.
L'archive ouverte pluridisciplinaire HAL, est destinée au dépôt et à la diffusion de documents scientifiques de niveau recherche, publiés ou non, émanant des établissements d'enseignement et de recherche français ou étrangers, des laboratoires publics ou privés. 


\title{
Dissolved uranium, vanadium and molybdenum behaviours during contrasting freshwater discharges in the Gironde Estuary (SW France)
}

\author{
Emilie Strady, Gérard Blanc, Jörg Scha“ fer*, Alexandra Coynel, Aymeric Dabrin \\ Universite' de Bordeaux, UMR 5805 EPOC, Av. des faculte's, 33405 Talence cedex, France
}

a r t i c le i n f o

\section{Article history:}

Received 6 February 2009

Accepted 5 May 2009

Available online 13 May 2009

\section{Keywords:}

uranium

vanadium

molybdenum

salinity gradient

Gironde Estuary

net fluxes

\begin{abstract}
$\mathrm{a} b \mathrm{~s}$ t $\mathrm{r}$ a c t
Understanding trace metal behaviour in estuarine environments requires sampling strategies and analytical methods adapted to strong physical and geochemical gradients. In this study, we present a specific sampling strategy covering a wide range of hydrological conditions during nine cruises in 20032007 to characterise the behaviour of three dissolved metals (uranium, vanadium and molyb- denum) in surface and bottom water along the salinity gradient of the highly turbid macrotidal Gironde Estuary using a solid-liquid extraction. Uranium behaved conservatively whatever the water discharges observed. The slight dissolved U depletion compared to the theoretical dilution line between the fluvial and marine end-members occasionally observed in the low salinity range $(0-3)$ was attributed to the mixing of different water bodies of the Gironde tributaries. In contrast, dissolved $\mathrm{V}$ behaviour was largely influenced by the hydrological conditions, showing increasingly pronounced addition with decreasing freshwater discharges, (i.e. increasing residence times of water and particles in the estuary). This addition of dissolved $\mathrm{V}$ in the low- to mid-salinity range was attributed to desorption processes observed in the Maximum Turbidity Zone (MTZ). The distribution of dissolved Mo concentrations along the salinity gradient was highly variable. Apparent conservative, and non-conservative behaviours were observed and were related to the concomitance of desorption from SPM, inputs from sediments for additive distribution and biological uptake and removal into sediments for subtractive distribution. Based on the whole database (2003-2007), annual net fluxes to the coastal ocean were estimated for dissolved U $\left(15.5-16.6 \mathrm{t} \mathrm{yr}^{-1}\right)$ and $\mathrm{V}\left(31.3-36.7 \mathrm{tyr}^{-1}\right)$.
\end{abstract}

\section{Introduction}

Estuaries play a major role in geochemical cycles of trace metals. Processes occurring in these mixing environments with various physical and chemical gradients affect the partitioning between particulate and dissolved phases reactivity and bioavailability of metals. Understanding trace metal behaviour is crucial for the assessment of potential impacts on the coastal ocean. In oxic aquatic freshwater environments, uranium (U), vanadium (V) and molybdenum (Mo) are present in their soluble oxidized state: U(VI) as bicarbonates complex in majority ( $\underline{\text { Osmond }}$ and Ivanovich, 1992), $\mathrm{V}(\mathrm{V})$ as $\mathrm{VO}_{2}(\mathrm{OH})^{2-}$ (Sadiq, 1988) and Mo(VI) as $\mathrm{MoO}_{4}^{2-}$ (Collier, 1985).

In most studied estuaries, $\mathrm{U}$ behaved conservatively along the salinity gradient (Windom et al., 2000). However, in few cases, some local depletion was observed in the low salinity range, and

\footnotetext{
* Corresponding author.

E-mail address: j.schaefer@epoc.u-bordeaux1.fr (J. Scha"fer).
}

was attributed to changes in alkalinity (Toole et al., 1987; Van Den Berg et al., 1991; Sarin and Church, 1994). Few papers have reported on $\mathrm{V}$ geochemistry in estuarine environments suggesting generally conservative behaviour (e.g. Scheldt and Rhine estuaries, Van der Sloot et al., 1985; Tamar Estuary, Van Den Berg et al., 1991). However, local subtraction was also observed and was attributed to local $\mathrm{O}_{2}$ depletion in the water column (Shiller and Mao, 1999), as its solubility is more important in oxic environments (Wehrli and Stumm, 1989; Emerson and Huested, 1991). In sediments, V may be released from pore water during Organic Matter (OM) degradation (Audry et al., 2006). Although, $\mathrm{V}$ is not considered as a priority pollutant (Directive 2000/60/EC, European Council, 2000)), it may have inhibitory effect on enzymatic activity (Jandhyala and Hom. 1983 ) and its concentration levels in bivalves is surveyed along the French coast (French National Mussel Watch programme RNO, 2006). In contrast, Mo is well known for its toxic effects (e.g. Goldberg et al., 2002), although it is also essential for $\mathrm{N}_{2}$-fixing cyanobacteria (Bortels, 1930; Fogg and Wolfe, 1954). Dissolved Mo abundance and biological activity are lower in the marine parts of estuaries (Howarth and Cole, 1985), reflecting its conservative 
behaviour observed in most estuaries. However, Mo removal from estuarine waters has also been observed (Dalai et al., 2005) and release into sediment pore water during early diagenesis followed by resuspension may locally and temporarily add dissolved Mo to the water column of the Gironde Estuary (Audry et al., 2007).

In this study we present dissolved $\mathrm{U}, \mathrm{V}$ and Mo concentrations and distributions along the salinity gradient of the Gironde Estuary, which are much less documented than those of other more commonly studied elements (e.g. $\mathrm{Cd}, \mathrm{Cu}$, etc.). Although the estuarine behaviour of dissolved $\mathrm{U}, \mathrm{V}$ and Mo has been studied in several estuaries, further investigations are required during contrasting hydrological conditions to (1) document and compare their respective behaviours along the salinity gradient of the same estuary, (2) report on their responses to variations in hydrological conditions and/or (3) present the net fluxes estimates of U, V, Mo exported out of the Gironde Estuary.

\section{Study area and methods}

\subsection{Gironde Estuary}

The Gironde Estuary is one of the largest $\left(625 \mathrm{~km}^{2}\right)$ fluvioestuarine systems of the European Atlantic Coast (Fig. 1). Its main tributaries, the Garonne and Dordogne Rivers, account for a mean annual freshwater input of $820 \mathrm{~m}^{3} \mathrm{~s}^{-1}$ (1990-2007 period; Port Autonome Bordeaux). The Gironde Estuary is a partially mixed to well-mixed meso- to macrotidal estuary with tidal amplitude of 1.5-5.5 m ( Hayes, 1975). During tidal cycle ocean water inputs have been estimated 30-40 times higher than fluvial inputs (Allen et al., 1977). The estimated residence time of fluvial water varies from a few days during flood events to w 86 days during low freshwater discharge (Castaing and Jouanneau, 1979; Saari et al., 2008). The asymmetrical progression of the tidal wave towards the upstream of the estuary and the residual density circulation induce a pronounced permanent Maximum Turbidity Zone (MTZ) with Suspended Particulate Matter (SPM) concentrations in surface waters superior to $1 \mathrm{~g} \mathrm{l}^{-1}$ (Castaing, 1981). The total suspended sediment mass in the MTZ has been estimated at w $5 \times 10^{6}$ tons (Jouanneau and Latouche, 1981).

\subsection{Sampling}

During 2003-2007, nine cruises were performed along the salinity gradient of the Gironde Estuary $(0-34)$ onboard the RV "Co^tes de la Manche", covering different seasons and a wide range of hydrological situations. The cruises included stable low water discharge situations (September 2006; $Q^{1 / 4} 169 \mathrm{~m}^{3} \mathrm{~s}^{-1}$; GIMERCAD2) and a flood period (March 2007; $Q^{1 / 4} 2600 \mathrm{~m}^{3} \mathrm{~s}^{-1}$; GIMERCAD3; Fig. 1), with an average annual freshwater discharge of w750 $\mathrm{m}^{3} \mathrm{~s}^{-1}$ during the 2003-2007 period (Fig. 1).

At each sampling point, salinity, temperature, $\mathrm{pH}$ and oxygen level were measured with a multi-parameter probe (YSI 6920) calibrated the same day. Surface water (1 m below air-water interface) and bottom water ( $1 \mathrm{~m}$ above water-sediment interface) were sampled with decontaminated 5-l Niskin bottles and immediately transferred into acid pre-cleaned PP bottles $(500 \mathrm{ml})$, previously rinsed with estuarine water of the site. Then, $130 \mathrm{ml}$ were immediately filtered through $0.2 \mathrm{~mm}$ Nucleopore ${ }^{\circledR}$ polycarbonate filters and split into two aliquots. One aliquot $(125 \mathrm{ml})$ was acidified (ultrapure $\mathrm{HNO}_{3}, 1 / 1000$ ) to a $\mathrm{pH}<2$ and stored in an acid pre-cleaned PP bottle at $4{ }^{\circ} \mathrm{C}$ in the dark until trace metal analysis. The second aliquot $(5 \mathrm{ml})$ was stored in a PP bottle at $-20^{\circ} \mathrm{C}$ until dissolved inorganic phosphate (DIP) analysis. Clean techniques were used to minimize contamination during sampling, handling and onboard analysis (Patterson and Settle, 1976).

Suspended Particulate Matter (SPM) concentrations were determined by filtration (Whatman GF/F, $0.7 \mathrm{~mm}$, pre-weighed) of precise water volumes. Filters were then dried onboard at $50{ }^{\circ} \mathrm{C}$ until constant weight and re-weighed in the laboratory. SPM for Particulate Organic Carbon (POC) analysis was retrieved by pumping and centrifugation of important volumes of estuarine waters (up to $400 \mathrm{l}$ ), as described in Schäfer et al. (2002) and dried at $45^{\circ} \mathrm{C}$.

\subsection{Laboratory analysis}

\subsubsection{Dissolved $U$, Vand Mo analyses by solid-liquid extraction and ICP-MS}

Analysing dissolved trace metals in estuarine waters has to deal with (1) low and variable concentrations along the salinity
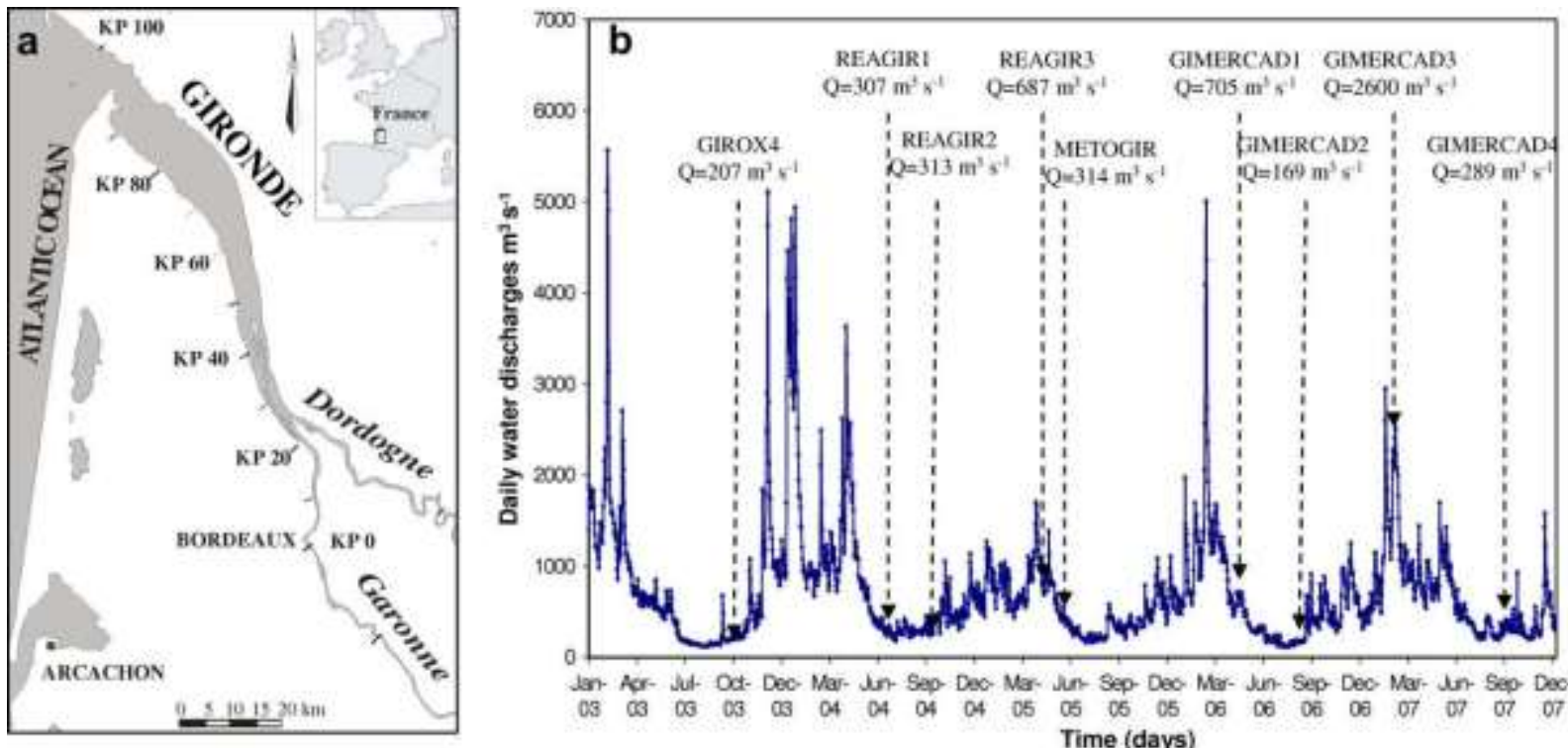

Fig. 1. a) Map of the Gironde Estuary and its two major tributaries, the Garonne and Dordogne Rivers; b) daily water discharge in the Gironde Estuary from January 2003 to December 2007. The nine sampling cruises are indicated by arrows. 
gradient, (2) changing sample matrixes due to estuarine processes (e.g. flocculation, OM degradation etc.) and (3) the presence of the salt matrix, known to induce significant physical and chemical interferences during ICP-MS analyses. Several adapted methods have been used to separately study $\mathrm{U}, \mathrm{V}$ and $\mathrm{Mo}$ in estuarine environments, based on metal specific procedures and material. For example, Windom et al. (2000) and Sarin and Church (1994) measured $U$ by ion-exchange combined to alpha counting and by isotope-dilution followed by ICP-MS quantification, respectively. Dissolved $\mathrm{V}$ concentrations were analysed using different techniques such as catalytic colorimetric methods (Shiller and Mao, 1999) and separation/preconcentration by Chelex $100^{\circledR}$ resin prior to ICP-AES measurements (Auger et al., 1999). Dilution of the saline matrix prior to direct ICP-MS measurement was used to determine dissolved Mo concentrations (Dalai et al., 2005). However, dilution only limits the physical interferences and cannot be applied to elements with too low concentrations and/or affected by isobaric interferences.

In this study, we analysed simultaneously dissolved $U\left(U_{D}\right), V$ $\left(V_{D}\right)$ and $M o\left(M_{D}\right)$ after matrix separation and preconcentration by solid-liquid extraction, using DigiSEP Blue ${ }^{\circledR}$ cartridges (SCP SCIENCE), with amino-di-acetate as the functional group. The setup consisted on a $6 \mathrm{ml}$ DigiSEP Blue ${ }^{\circledR}$ cartridge coupled to an acid precleaned PP reservoir $(70 \mathrm{ml})$ at the top and to a peristaltic pump (Gilson; $2 \mathrm{ml} \mathrm{mn}^{-1}$ ) and tub at the bottom. The matrix separation/ preconcentration procedure is based on the method reported by Kingston et al. (1978) and is divided into four steps (Fig. 2). Each step and parameter (flow rate, $\mathrm{pH}$, reagent volumes, preconcentration factors, etc.) of the procedure was controlled and optimised to obtain low blank values, best recoveries and reproducibility of metal analyses (Table 1). The evolution of the ("single-use") cartridge performances during multiple-use and -regeneration cycles of the same cartridge (more than 50 separation-regeneration cycles) has also been assessed (Table 1). This rapid and economic matrix separation and preconcentration technique has proven to be

\section{Conditioning}

Add $5 \mathrm{ml}$ of $2 \mathrm{M} \mathrm{HNO}_{3}$ plasma pur $\mathbb{R}$

Add $5 \mathrm{ml}$ of Milli-QB water

Add $5 \mathrm{ml}$ of $0.1 \mathrm{M}$ Ammonium Acetate ( $\mathrm{pH} 5.5$ )

\begin{tabular}{|c|}
\hline $\begin{array}{c}\text { Sample addition } \\
\text { Add } 60 \mathrm{ml} \text { of sample pre-adjusted at } \mathrm{pH} 5.5 \\
(1 \mathrm{ml} 1 \mathrm{M} \text { Ammonium Acetate buffer } \\
+ \text { ammoniac suprapur }(\mathbb{B})\end{array}$ \\
\hline
\end{tabular}

\section{Rinsing \\ Rinse $5 \mathrm{ml} 0.1 \mathrm{M}$ Ammonium Acetate ( $\mathrm{pH} 5.5$ ) Add $5 \mathrm{ml}$ of Milli-Q® water}

\begin{tabular}{|c|}
\hline $5 \mathrm{ml}$ of $2 \mathrm{M}^{\text {Elution }} \mathrm{HNO}_{3}$ plasma pur $\mathbb{B}$ \\
\hline Add $9 \mathrm{ml}$ of Milli-Qß) water \\
ICP-MS analysis (Thermo X7) \\
\hline
\end{tabular}

Fig. 2. Protocol steps of the solid-liquid extraction using DigiSEP Blue ${ }^{\circledR}$ cartridge
Table 1

Quality control of the solid-liquid extraction. Blankvalues $\left(\mathrm{mgl}^{-1}\right)$, detection limit ( 3 S of blanc values, $n 1 / 4160$ ), reproducibility between cartridges and for multiple use, measured metal concentrations $\left(\mathrm{mgl}^{-1}\right)$ and recoveries are presented for $\mathrm{U}, \mathrm{V}$ and Mo.

\begin{tabular}{|c|c|c|c|c|}
\hline & & $\mathrm{U}$ & V & Mo \\
\hline Blank values & mean & 0.001 & 0.002 & 0.010 \\
\hline$n 1 / 4160$ & standard deviation & 0.002 & 0.004 & 0.011 \\
\hline Detection limit 3s & & 0.001 & 0.016 & 0.010 \\
\hline $\begin{array}{l}\text { Reproducibility } \\
\text { between cartridges }\end{array}$ & RSD & $2 \%$ & $1 \%$ & $5 \%$ \\
\hline $\begin{array}{l}\text { Multiple use } \\
\qquad(n 1 / 450)\end{array}$ & RSD & $<10 \%$ & $<10 \%$ & $<10 \%$ \\
\hline CASS- 4 & certified values & 3 & $1.18 \mathrm{~T} 0.16$ & $8.78 \mathrm{~T} 0.86$ \\
\hline \multirow[t]{3}{*}{$n n^{1 / 418}$} & measured values & $2.7 \mathrm{~T} 0.17$ & $1.17 \mathrm{~T} 0.10$ & 6.2 Т 0.7 \\
\hline & recovery & $90 \%$ & $100 \%$ & $66 \%$ \\
\hline & reproducibility RSD & $6 \%$ & $9 \%$ & $11 \%$ \\
\hline NASS-5 & certified values & 2.6 & 1.2 & $9.6 \mathrm{~T} 1.0$ \\
\hline \multirow[t]{3}{*}{$n^{1 / 49}$} & measured values & $2.55 \mathrm{~T} 0.31$ & $1.15 \mathrm{~T} 0.12$ & $6.93 \mathrm{~T} 0.97$ \\
\hline & recovery & $98 \%$ & $96 \%$ & $72 \%$ \\
\hline & reproducibility RSD & $12 \%$ & $10 \%$ & $14 \%$ \\
\hline
\end{tabular}

reliable and adapted for the simultaneous determination of $U_{D}, V_{D}$ and MoD in estuarine and coastal seawater samples.

Concentrations of $U_{D}, V_{D}$ and MoD were then measured by ICPMS (Thermo X7) with external calibration under standard conditions. Accuracy and analytical precision were continuously quality checked for all the cartridges used by analysis of international certified reference materials (CASS-4; NASS-5; Table 1). This method provided quantitative recoveries (>97\%) and excellent precision (Table 1 ) for $U_{D}$ and $V_{D}$, when using the same cartridge several times (25-50 times) and for different cartridges (Table 1). Molybdenum showed lower recoveries of $66 \%$ (CASS-4, $n 1 / 419$ ) and $70 \%$ (NASS-5, $n$ 1/49). However, suitable precision and reproducibility between cartridges allowed correcting MoD concentrations to $100 \%$ recovery. This correction did not modify the observed distribution of MoD along the Gironde Estuary salinity gradient, where dissolved Mo concentrations varied by a factor of w 30 (Fig. 5 ).

\subsubsection{Particulate Organic Carbon (POC) and Dissolved Inorganic Phosphate (DIP) analyses}

Representative aliquots (w50 mg) of dry, homogeneized SPM samples were acidified with $\mathrm{HCl}(2 \mathrm{M})$ to remove carbonates and dried at $60{ }^{\circ} \mathrm{C}$ for $24 \mathrm{~h}$. Samples were then analysed with a LECO CS-125 analyser with precision better than 5\%, according to the method described in Etcheber et al. (1999). POC contents are expressed as percentage of dry weight of SPM, abbreviated as POC\%. DIP was analysed within a month after sampling according to the ascorbic acid-molybdate blue method (Murphy and Riley, 1962) and measured spectrophotometrically.

\section{Results}

\section{Hydrological conditions}

Based on the freshwater discharges of both major tributaries (Garonne and Dordogne Rivers), the hydrological situations during the 9 cruises between September 2003 and October 2007 can be classified into 4 contrasting water level types: exceptional drought (<200 $\mathrm{m}^{3} \mathrm{~s}^{-1}$ : 09/27/03, GIROX4; 09/07/06, GIMERCAD2), typical low freshwater discharge (w300 $\mathrm{m}^{3} \mathrm{~s}^{-1} ; 07 / 18 / 04$, REAGIR1; 10/09/04, REAGIR2; 07/08/05, METOGIR; 10/01/07, GIMERCAD4), low/mean water discharge (w700 $\mathrm{m}^{3} \mathrm{~s}^{-1}: 05 / 10 / 05$ REAGIR3; 05/12/06, GIMERCAD1) and flood (w2 $600 \mathrm{~m}^{3} \mathrm{~s}^{-1}$; 03/04/ 07, GIMERCAD3) were observed. 

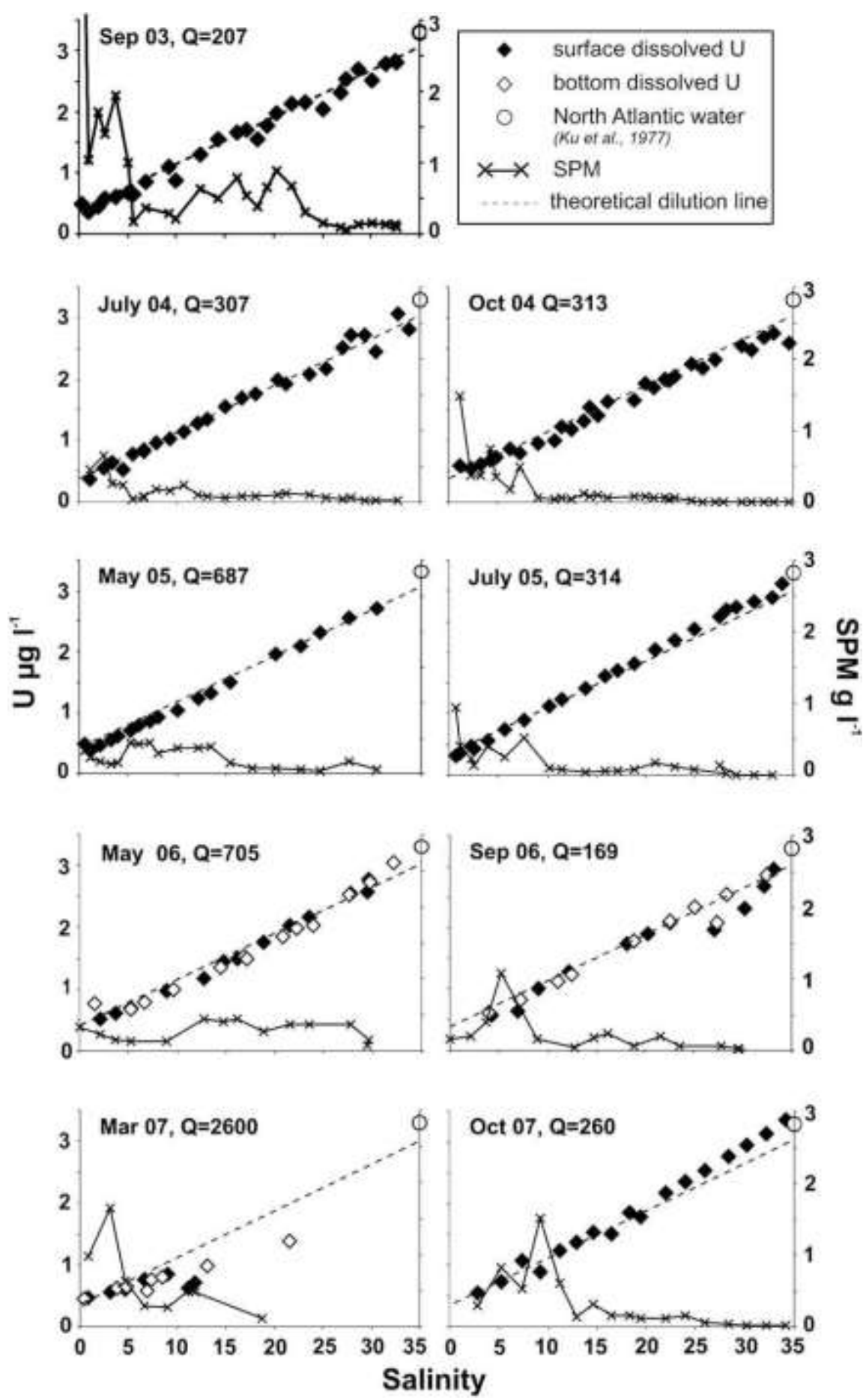

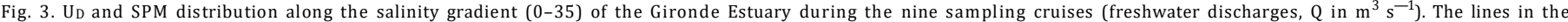

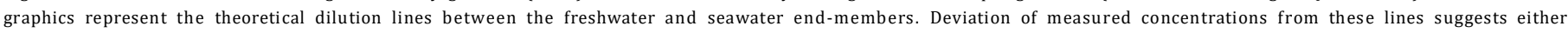
addition or subtraction.

\subsection{SPM and DIP distribution along the salinity gradient}

Relation between spatial distribution and concentrations of SPM, hydrological conditions and intrusion of saline waters in the Gironde Estuary are well-documented (Jouanneau et al.. 1983. Elbaz-Poulichet et al., 1984; Sottolichio and Castaing, 1999). In the present study, maximum SPM concentrations in surface water (6000 $\mathrm{mg} \mathrm{l}^{-1}$; September 2003) were generally observed during severe drought level and the presence of the MTZ is mainly localized from freshwater to a mid-salinity range to $S 1 / 415-20$ due to low fluvial water discharges (Figs. 3-5). In May 2005 and 2006 (REAGIR3, GIMERCAD1), maximum concentrations were observed at mid-salinity range, probably caused by low/mean water levels. Afterwards, concentrations decreased roughly until values less than $10 \mathrm{mg} \mathrm{l}^{-1}$ (seawater endmember; Figs. 3-5). 

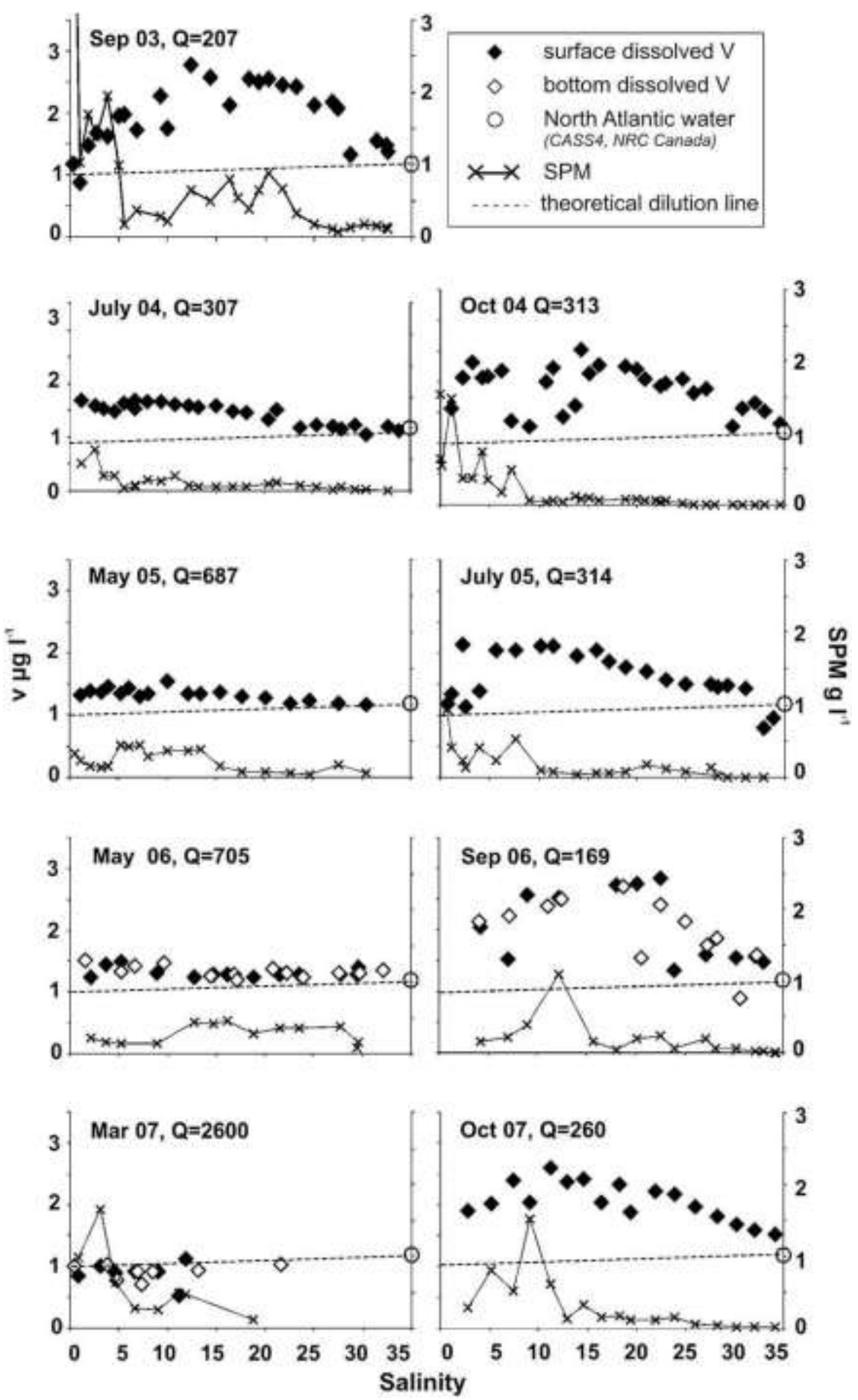

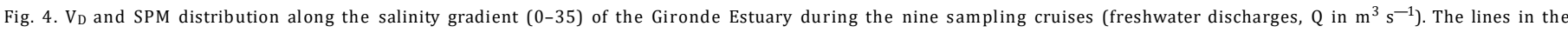

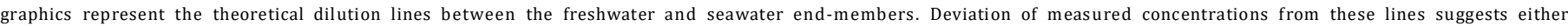
addition or subtraction.

In October 2007, DIP concentrations along the salinity gradient showed a typical bell-shaped distribution, with decreasing concentrations towards the higher salinity corresponding to seawater dilution (Fig.6; Deborde et al., 2007).

\subsection{Uranium distribution along the salinity gradient}

Dissolved U concentrations measured for the 9 longitudinal profiles ranged from 0.32 to $3.37 \mathrm{mgl}^{-1}$ and were similar for both surface and bottom water of the same salinity (Fig. 3). (s.d.<5\%; cf. May 2006, October 2006, September 2007). Note that these concentrations are in the same range as those observed by Windom et al. (2000) in other estuaries. In the Gironde Estuary, $U_{D}$ concentrations at the main freshwater end-member (Garonne River, contributing $\mathrm{w} 70 \%$ of freshwater and $\mathrm{w} 80 \%$ of dissolved $\mathrm{U}$ ) were clearly lower $\left(0.50 \mathrm{~T} 0.10 \mathrm{mg}^{-1}\right)$ than the seawater endmember (3.3 T $0.3 \mathrm{mg}^{-1}$; $S 1 / 434.1$ ), which reached slightly lower concentrations than typical values of North Atlantic oceanic 

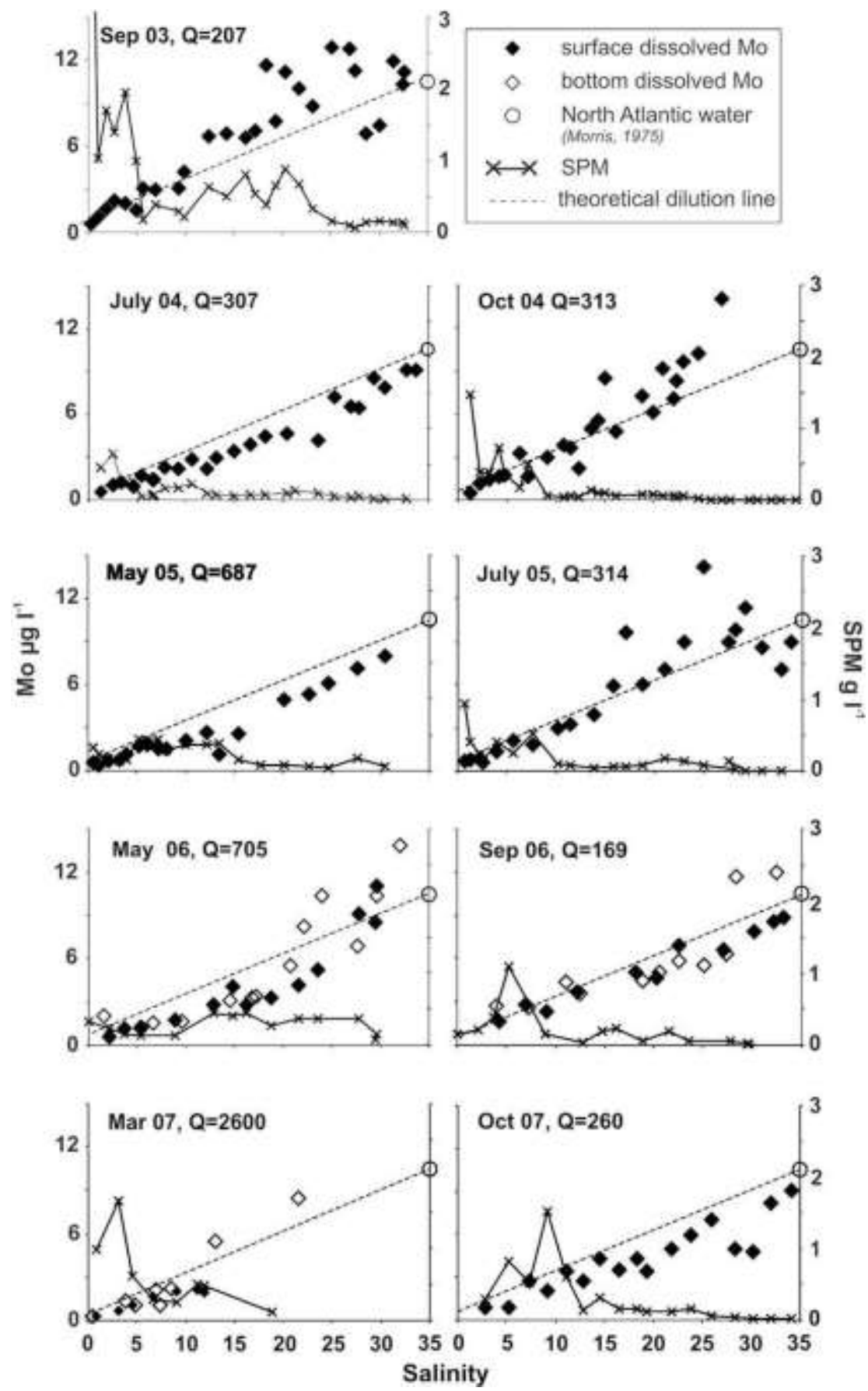

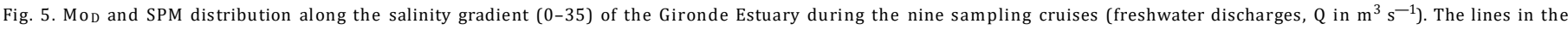

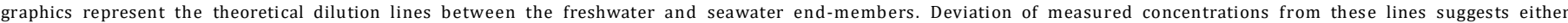
addition or subtraction.

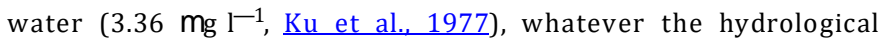
situation. Between these two end-members, $U_{D}$ concentrations followed the theoretical dilution line indicating conservative behaviour whatever the hydrological situation and the MTZ position/intensity. Only at few points in the low salinity range, $U_{D}$ concentrations plotted below the dilution line (Fig. 3). The

differences between measured and expected values (w $0.25 \mathrm{mg}^{-1}$ ) cannot be explained by analytical uncertainties (Table 1) suggesting that this represents a local and/or temporal anomaly (cf. 4. Discussion).

\subsection{Vanadium distribution along the salinity gradient}

Dissolved $\mathrm{V}$ concentrations were similar in surface and bottom water of the same salinity (s.d.<6\%; cf. May 2006, October 2006, September 2007; Fig. 4). They ranged from $0.89 \mathrm{mgl}^{-1}$ to $2.76 \mathrm{mgl}^{-1}$ (Fig. 4), which is higher than those measured in the English Channel (0.76-1.43 $\mathrm{mg} \mathrm{l}^{-1}$; Auger et al., 1999) and on the Louisiana Shelf (0.32-1.70 $\mathrm{mg} \mathrm{l}^{-1}$; Shiller and Mao, 1999). The $\mathrm{V}_{\mathrm{D}}$ concentration levels were rather similar (1.0-1.5 $\left.\mathrm{mg} \mathrm{l}^{-1}\right)$ in the freshwater and seawater end-members (North Atlantic Coastal Ocean values 

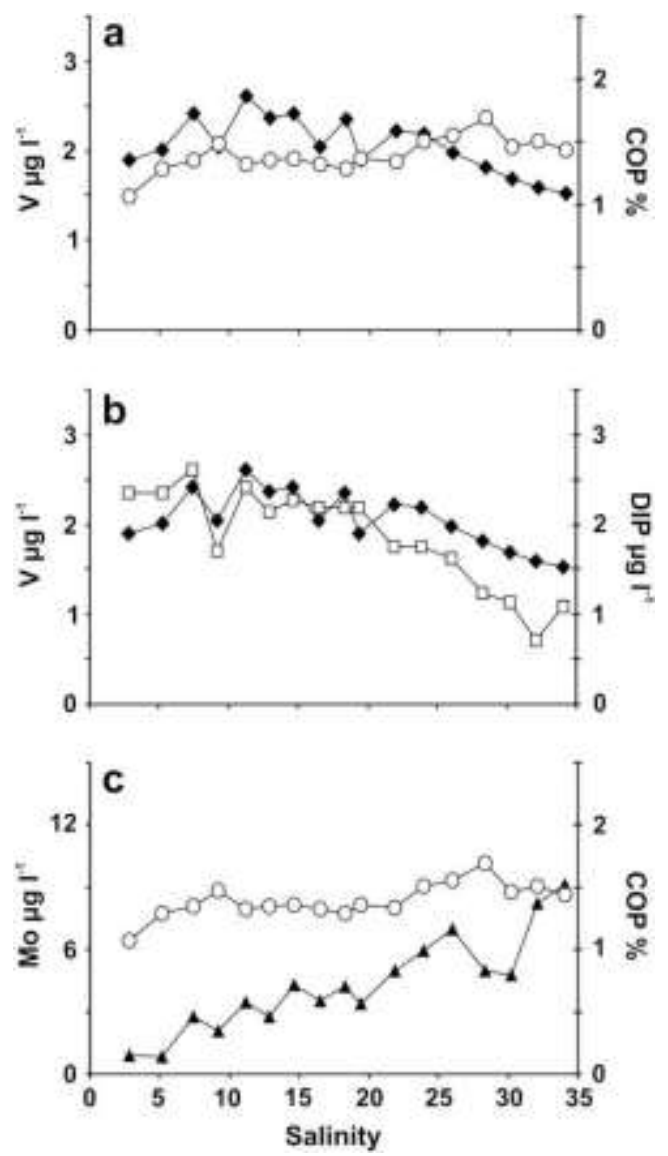

Fig. 6. Relation between a) $\mathrm{V}_{\mathrm{D}}$ (black diamond; $\mathrm{mg} \mathrm{l}^{-1}$ ) and POC\% (white circle), b) $\mathrm{V}_{\mathrm{D}}$ (black diamond; $\mathrm{mgl}^{-1}$ ) and DIP (white square) and c) MoD (black triangle; $\mathrm{mg}^{-1}$ ) and POC\% (white circle) along the Gironde Estuary salinity gradient (0-35) during October 2007.

w1.18 $\mathrm{mgl}^{-1}$,e.g. CASS-4; Morris, 1975) and followed (conservative; e.g. March 2007) or not (non-conservative) the theoretical dilution lines.

\subsection{Molybdenum distribution along the salinity gradient}

Along the salinity gradient, high spatial differences (factor 30) were observed for both surface and bottom dissolved Mo concentrations (Fig. 5). Surface values ranged from $0.32 \mathrm{~T}^{2} 0.2 \mathrm{mgl}^{-1}$ at the freshwater end-member to $9.16 \mathrm{~T}^{2} 2.0 \mathrm{mgl}^{-1}$ at the seawater endmember (North Atlantic Oceanic water $10.5 \mathrm{mg} \mathrm{l}^{-1}$; Morris, 1975), which are in the same range than those observed in the Chao Phraya River Estuary (0.02-11.2 $\mathrm{mgl}^{-1}$, Dalai et al., 2005). However, in September 2003, October 2004 and July 2005, higher local values (until $14.1 \mathrm{mg} \mathrm{l}^{-1}$ ) were observed at high-salinity range (Fig. 5). Between both end-members, Mo ${ }_{D}$ showed very different distribution patterns with 1) $\mathrm{Mo}_{\mathrm{D}}$ concentrations following the theoretical dilution line (conservative behaviour; e.g. July 2004, September 2006), 2) Mod subtraction in the mid-salinity range (May 2005, May 2006, October 2007) or 3) MoD addition in the mid- to highsalinity range (September 2003, October 2004; Fig. 5). Like $U_{D}$ and $V_{D}$, Mod concentrations showed similar distribution patterns in surface and bottom water. However, bottom water values were lower during May 2006 and September 2006, representing 70$100 \%$ of surface water concentrations, whereas during March 2007 bottom water values were higher.

\section{Discussion}

1. Uranium

The sampling strategy applied during contrasting freshwater discharges showed profiles where surface and bottom $U_{D}$ followed the theoretical dilution line between the marine and freshwater end-members, suggesting globally conservative behaviour in the Gironde Estuary, except for locally and temporarily apparent subtraction in the low salinity range (Fig. 3). Conservative U behaviour is coherent with what has been observed for most estuaries (e.g. Windom et al., 2000). However, local subtraction has also been reported in the Amazon shelf (Swarzenski et al., 1995), in the Savannah Estuary (Windom et al., 2000), and in Delaware and Chesapeake estuaries (Sarin and Church, 1994), where it was attributed to important $U$ sequestration in salt marshes ( $\underline{\text { Church }}$ et al., 1996). In the Gironde Estuary, previous studies have reported both conservative behaviour inferred from dissolved ${ }^{238} \mathrm{U}$ activities measured in the Gironde fluvial-estuarine system (Saari et al. 2008) and non-conservative $U$ behaviour suggesting $U_{D}$ removal in the low salinity range (Smith et al., 2001; Audry et al., 2007). This apparent $U_{D}$ variation may probably reflect variable contributions of the Dordogne River (0.2 T $0.1 \mathrm{mg} \mathrm{l}^{-1}$; Masson, 2007) or the Garonne River (0.6 $0.1 \mathrm{mgl}^{-1}$; pers. comm.) draining U-rich areas with Permian outcrops (Coynel et al., 2007). However, these anomalies are rather small and do not affect the overall distribution of $U_{D}$ along the salinity gradient (Fig. 3). The eight $U_{D}$ profiles obtained during severe drought level to mean freshwater discharge closely followed the dilution line, with increasing amplitude of concentrations (up to $13 \%$ ) towards the higher salinity (seawater end-member October 2004: $2.7 \mathrm{mg} \mathrm{l}^{-1}$; October 2007: $3.3 \mathrm{mg} \mathrm{l}^{-1}$; Fig. 7). Those variations could be attributed to (1) destabilization of uranyl carbonate complex and/or (2) biological uptake and/or (3) U adsorption to metal oxides at the water-sediment interface during tidal flooding over intertidal mud flats (Barnes and Cochran, 1993; Shaw et al., 1994; Church et al., 1996). The equation of the relation U/salinity (Fig. 7) is slightly different from that reported by Audry et al. (2007), as the authors based the relation on water sampled from salinity 0-19 and on higher riverine end-member concentrations (see discussion above). Thus, the hypothesis of U sequestration by the sediment of the Gironde Estuary up to 50\% (Audry et al.. 2007) could be considered as over-estimated, as no clear subtractive behaviour was observed along the salinity gradient during the nine cruises discussed here. However, similar surface and bottom $U_{D}$ concentrations (Fig. 3) support the work of Audry

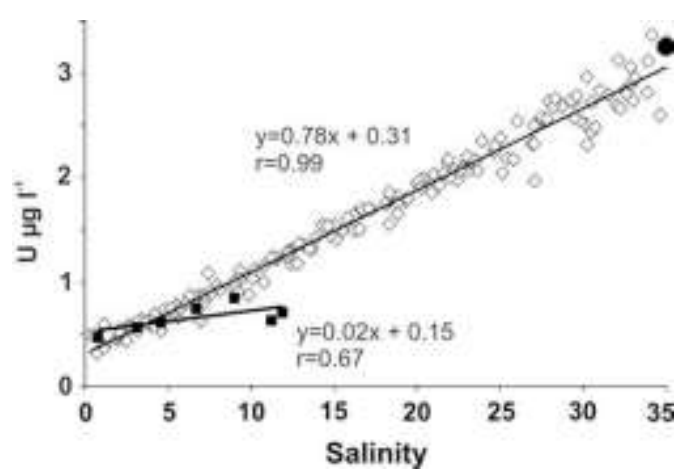

Fig. 7. Distributions of $U_{D}$ concentrations $\left(\mathrm{mg} \mathrm{l}^{-1}\right)$ measured along the salinity gradient White diamonds represent concentrations measured during drought level to medium freshwater discharge conditions. Black squares represent concentrations measured during the flood event (March 2007). Black circle corresponds to the $U_{D}$ of North Atlantic Oceanic water. 
et al. (2007) reporting (1) negligible inputs of $U$ from sediments, soft mud and dredging-related resuspension (estimated at $0.5 \%$, $0.3 \%$ and $0.2 \%$, respectively, of annual fluvial inputs) and (2) inefficient $\mathrm{U}$ sequestration.

During the flood event (March 2007), the distribution showed lower concentrations with larger amplitude (from salinity 1-12; Fig. 7) suggesting a non-conservative and un-equilibrated distribution. In fact, during floods, the water residence time in the estuary is greatly reduced, and may be not sufficient to allow complete mixing of freshwater masses of different origins (Dordogne and Garonne Rivers) and saltwater bodies, inducing a more 'noisy' distribution between the two end-members.

\subsection{Vanadium}

$\mathrm{V}_{\mathrm{D}}$ behaviour along estuarine salinity gradients is few documented and has never been studied in the Gironde Estuary. The present data set aims at documenting $V_{D}$ behaviour in this estuary for contrasting freshwater discharges. Distributions of $V_{D}$ in the Gironde Estuary followed non-conservative behaviour. During drought and very low water discharge, the summits of the bell-shaped concentration curves (similar to those observed for Cd; Kraepiel et al., 1997. Michel et al., 2000) along the salinity gradient reached values of up to w3-fold higher than values expected for conservative mixing (Fig. 4). Moreover, during mean river discharge and especially during flood, the $V_{D}$ distribution along the salinity gradient followed the theoretical dilution line, probably due to a higher dilution of added $V_{D}$. This $V_{D}$ behaviour is original and clearly different from those reported for the Rhine, Scheldt (Van der Sloot et al., 1985) and Tamar estuaries (Van Den Berg et al., 1991), where $V_{D}$ behaviour was non-conservative at low salinity and conservative in the mid- to high-salinity range. The sampling strategy revealed sensitivity of apparent $V_{D}$ behaviour to freshwater discharge, i.e. addition becoming more visible during low freshwater discharge.

Vanadium addition in both, surface and bottom waters of the Gironde Estuary suggests that $\mathrm{V}$ dissolution prevails over sequestration (September 2006, Fig. 4), even in bottom water of the MTZ which may be strongly $\mathrm{O}_{2}$-depleted during low discharges (Robert et al., 2004; Audry et al., 2006). In the water column, increasing $V_{D}$ during drought to low/mean freshwater discharge may reflect (1) release from $0 \mathrm{M}$ degradation and/or (2) desorption from SPM. In general, OM degradation in the MTZ results in decreasing POC in surface SPM. Thus, increasing $V_{D}$ with decreasing POC was reported to result from $\mathrm{OM}$ degradation processes in the Tyro and Bannock Basins (Van der Weijden et al., 1990). However, no such relationship between $V_{D}$ and POC occurred during different situations (e.g. October 2007, typical low water level, Fig. 6a), suggesting that $0 \mathrm{M}$ degradation in the water column did not release $V_{D}$, in contrast to the soft mud of the Gironde Estuary freshwater reaches (Audry et al., 2006). In this estuary, additive phosphate behaviour along the salinity gradient has been attributed to predominance of desorp-

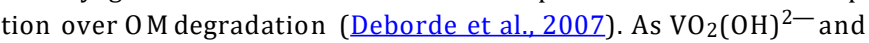
$\mathrm{HPO}_{4}^{2-}$ are two oxi-anions stereochemically close, we compared their distribution during October 2007 (Fig. 6b). Increasing $V_{D}$ and phosphate concentrations suggest that $\mathrm{V}_{\mathrm{D}}$ addition may be due to desorption processes occurring in the water column. The $\mathrm{V}$ desorption efficiency in the MTZ was experimentally assessed by mixing freshwater SPM with river water and low salinity estuarine water $(S<2$; pers. comm.), suggesting that $10-50 \%$ of particulate $V$ may be desorbed from Garonne River particles by saline estuarine waters, depending on salinity and solid/liquid mixing proportions (reflecting SPM concentrations). Applying this range of potential desorption to the $V_{D}$ data of the different profiles in the estuary and to particulate $\mathrm{V}$ fluxes in the Garonne River, suggested that desorption of $10-20 \%$ of particulate $V$ entering the estuary may explain the observed addition in the salinity gradient and the resulting net $V_{D}$ fluxes at the estuary mouth (see below). Accordingly, long water and particle residence time during low discharge may result in maximum $V_{D}$ desorption from SPM and explain the observed maximum $V_{D}$ concentrations in the mid-salinity range.

\subsection{Molybdenum}

Few studies have reported distribution of MoD along estuarine salinity gradients (Head and Burton, 1970; Dalai et al., 2005; Audry et al., 2007). Based on monthly monitoring profiles on the Chao Phraya Estuary, Dalai et al. (2005) have reported a strong linear relationship between salinity and $M_{D}$, suggesting conservative behaviour. In the present study, the sampling strategy revealed a wide range of different $\mathrm{Mo}_{\mathrm{D}}$ behaviours: rather conservative (July 2005, September 2006; Audry et al., 2007), additive (September 2003, October 2004) and subtractive (July 2004, May 2005, May 2006 and October 2007; Fig. 5). During severe drought, both subtractive (September 2006) and additive (September 2003) profiles were observed, suggesting that hydrological conditions alone cannot explain MoD distributions along the salinity gradient of the Gironde Estuary (which was observed for $V_{D}$ distribution). Therefore, intra-estuarine processes were investigated in order to better understand the variable $\mathrm{Mo}_{\mathrm{D}}$ behaviours.

\subsubsection{Additive Mo distribution}

The possible processes contributing to additional $\mathrm{Mo}_{\mathrm{D}}$ in the estuary are 1) $0 \mathrm{M}$ degradation in the MTZ, 2) MoD release from reductive processes in the MTZ, 3) MoD desorption from SPM and 4) inputs from sediment. During early diagenesis, Mo is partly released from $\mathrm{OM}$ degradation into the soft mud pore water and from reduction of Mn-oxides (Robert, 2003; Audry et al., 2006). The first hypothesis of Mo release associated to $\mathrm{OM}$ degradation in the MTZ (such as early diagenesis), was investigated by comparing POC and $\mathrm{MoD}_{\mathrm{D}}$ (as for $\mathrm{V}$, part 4.2.). Distributions did not exhibit close correlation (Fig. 6c), suggesting low MoD release from OM mineralisation in the downstream part of MTZ, where addition occurred. Reductive dissolution of $\mathrm{Mn}$-oxides and increasing $\mathrm{Mn}^{2 \mathrm{p}}$ concentrations $\left(\mathrm{Mn}_{\mathrm{D}}\right.$ ) in bottom water (reduction of $\mathrm{Mn}_{x} \mathrm{O}_{y}$ to $\mathrm{Mn}^{2} \mathrm{p}$; e.g. Froelich et al., 1979) were reported for the Gironde Estuary (e.g. Audry et al., 2006). As Mo release from Mn-oxides reduction occurs in the Gironde Estuary sediments (Robert, 2003), we tested this hypothesis for the present data set from the MTZ. For this, we plotted $M O_{D}$ and $\mathrm{Mn}_{\mathrm{D}}$ concentrations (measured by solid-liquid extraction and GF-AAS measurement) in the Gironde sediments together with the respective values in surface and bottom water of the nine profiles (Fig. 8). In the sediments, two relationships linking MoD to OM degradation on the one hand and to Mn-oxides reduction on the other were clearly established (Fig. 8a; Robert, 2003). Although $M n_{D}$ concentrations in the water column were clearly lower than in the sediment, MoD tended to increase with increasing $\mathrm{Mn}_{\mathrm{D}}$, as observed in the sediment. The relationship however was not significant (Fig. 8b). Accordingly, OM degradation and reductive processes in the MTZ may probably play a minor role in the observed MoD addition.

Maximum Mo adsorption on oxide minerals occurs in oxic environment at pH 3-5 and at low ionic strength (Wedepohl, 1978; Shimmield and Price, 1986; Goldberg et al., 1996; Goldberg and Forster, 1998). Thus, in estuarine waters with pHw7-8 and increasing ionic strength, Mo is likely to be desorbed from SPM to the water (Jones, 1975; Smedley et al., 2002). We estimated the excess Mo concentrations to those expected from the theoretical mixing line to $30-40 \%$ of the theoretical value (up to $110 \%$ in October 2004). The experimentally assessed potential desorption of Mo from Garonne River SPM suggested that $10-50 \%$ of particulate 

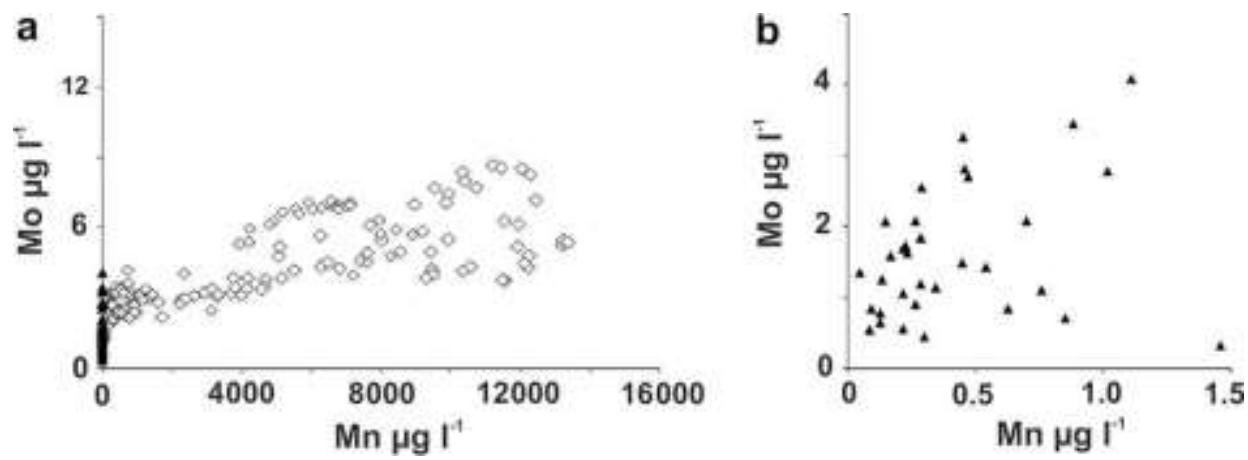

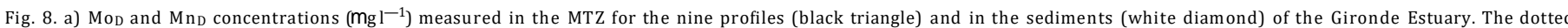

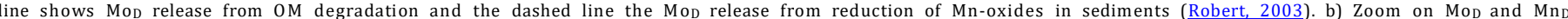
concentrations $\left(\mathrm{mgl}^{-1}\right)$ in surface water of the MTZ during the nine profiles (black triangle).

Mo concentrations may be desorbed in the turbidity gradient, depending on SPM concentrations (pers. comm.). In contrast to the case of $\mathrm{V}$, the potential Mo desorption from fluvial SPM cannot account for the 'excess MoD' along the salinity gradient, even when assuming the maximum potential desorption of $50 \%$. Thus, in the

Gironde Estuary, SPM desorption probably contributes to $\mathrm{Mo}_{\mathrm{D}}$ addition, but is far from being the only/dominant process involved. In contrast to $U_{D}$ and $V_{D}$, higher Mo concentrations were observed in bottom water than in surface water for $S \leq 10$, during the flood (March 2007; Fig. 6), and also during subtractive distribution in May and September 2006 along the whole salinity gradient, suggesting MoD release from sediment to the water column (estimated to $0.17 \mathrm{t}$ year by Audry et al., 2006). This may probably be attributed to (1) release of interstitial water and/or (2) resuspension of Mo-rich particles, which may be degraded in the water column. Suboxic sediments were reported to show Mo enrichments in polyframboids (iron sulfide microniches) together with low levels of redox sensitive metals (e.g. U, V), suggesting Mo sequestration from porewater even before pyrite concretion form by sulphate reduction (Elbaz-Poulichet et al., 2005; Tribovillard et al., 2008). In the Gironde sediments, intense sulphate reduction provides enough sulphide ( $>0.1 \mathrm{mM}$ ) to support precipitation of authigenic Mo sulfides (with or without Fe; Zheng et al., 2000; Audry et al., 2006, 2007). Thus, assuming that Mo-rich particles may theoretically form in the suboxic zone of Gironde sediments, remobilisation of surface sediment (e.g. dredging activity) could transfer these particles into the oxic bottom water, where their dissolution may induce addition of $\mathrm{MO}_{\mathrm{D}}$, whereas $U_{D}$ and $V_{D}$ remain unchanged.

\subsubsection{Subtractive Mo distribution}

Subtractive Mo behaviour was observed in July 2004, May 2005, May 2006 and October 2007 (Fig. 5). Possible explanations for the apparent $\mathrm{Mo}_{\mathrm{D}}$ subtraction are (1) biological uptake and/or (2) Mo sequestration by sediments. Molybdenum is known as a central component of several enzymes essential to $\mathrm{N}_{2}$-fixing cyanobacteria plankton (e.g. Bortels, 1930; Fogg and Wolfe, 1954; Marino et al., 2003). Thus, local $\mathrm{Mo}_{\mathrm{D}}$ depletion in high $\mathrm{Mo}_{\mathrm{D}}$-concentrated seawater can be connected to temporary phytoplankton uptake (e.g. Manheim and Landergren, 1978), as observed in the Southampton Waters (Head and Burton, 1970). In the Gironde Estuary, Chlorophyll-a distribution along the salinity gradient suggests primary production from spring to beginning of autumn, except in the MTZ (Irigoien and Castel, 1997). Accordingly, primary production in spring and autumn may also contribute to the $\mathrm{Mo}_{\mathrm{D}}$ subtraction observed downstream from the MTZ in July 2004, May 2005, May 2006, September 2006 and October 2007 (Fig. 5).
In the Gironde Estuary, Mo removal from sediment porewater was observed but considered negligible for the water column as Mo $\mathrm{D}$ distribution was close to the theoretical dilution line (Audry et al., 2007). However, we revised this hypothesis and considered that Mo sequestration could influence Mo distribution because (1) variable Mo behaviours including subtraction were observed for the present data set and (2) precipitation of authigenic Mo is possible (see discussion part 4.3.1.). Still, quantifying Mo removal remains difficult as the approach described by Li and Chan (1979) cannot be applied (Mo-salinity relationship intercept corresponds to negative concentrations). We proposed then a different method to estimate the daily 'deficit Mo' over a whole profile by subtracting the observed MoD concentrations to the theoretical concentrations given by the conservative distribution between end-members. The removal rate $\mathrm{R}\left(\mathrm{kg} \mathrm{d}^{-1}\right)$, defined as: $R 1 / 4 Q^{*} \mathrm{dMo}$, where $Q$ is the daily river water input into the estuary $\left(690 \mathrm{~m}^{3} \mathrm{~s}^{-1}\right.$ May 2005), and dMo the mean 'Mo deficit' over the salinity gradient (1.23 $\mathrm{mg} \mathrm{l}^{-1}$, May 2005), was of $73 \mathrm{~kg} \mathrm{~d}^{-1}$. This removal represents more than seven times the dissolved fluvial inputs $(10$ $\mathrm{kg} \mathrm{d}^{-1}$, unpublished data) and points out the major role of the ocean end-member on the Gironde Mod distribution. However, this removal rate was not estimated over a year because of the highly dynamic MoD distributions.

\subsubsection{Molybdenum balance}

For the nine profiles, Mo $o_{D}$ distributions changed fromaddition to subtraction, showing concentrations with similar distances from the theoretical dilution line (e.g. September 2003 and 2006, Fig. 6). Daily $\mathrm{Mo}_{\mathrm{D}}$ addition may be estimated from the difference between net MoD fluxes at the estuary mouth (Boyle et al., 1974, 1982; see next Section 4.4.) and daily gross Mo $\mathrm{D}$ fluxes entering the estuary. In July 2005, addition observed was of $190 \mathrm{~kg} \mathrm{~d}^{-1}$ (e.g. net fluxes $200 \mathrm{~kg} \mathrm{~d}^{-1}$, gross fluxes $10 \mathrm{~kg} \mathrm{~d}^{-1}$ ) which suggested that, at the daily timescale, MoD addition (July 2005) and subtraction (May $2005,73 \mathrm{~kg} \mathrm{~d}^{-1}$ ) over three months may be relatively of the same order. Assuming that none of these processes prevails, one may suppose that addition and subtraction widely counterbalance each others and that the resulting mass balance is not very different from what would be expected from conservative behaviour Accordingly, the observed highly dynamic $\mathrm{Mo}_{\mathrm{D}}$ behaviour probably results from the concomitance of reversible release/sequestration cycles involving SPM, biological uptake and water-sediment exchanges, and their kinetic balances with respect to water residence time (up to 3 months; Castaing and Jouanneau, 1979; Saari et al. 2008). Physical estuarine phenomena such as tidal currents, tidal bore, flood events or dredging play an important role on 
estuarine sediment resuspension and may therefore act as key factors influencing the $\mathrm{Mo}_{\mathrm{D}}$ distribution between the riverine and ocean end-members of this estuary.

\subsection{Estimation of net fluxes to the coastal ocean}

Estuaries play a major role in trace metal transport at the continent-ocean interface. Dissolved and particulate metal fluxes entering the Gironde Estuary (gross fluxes) have been well-documented due to long-term high-resolution observation at the different fluvial entries (e.g. Scha" fer et al,, 2002; Masson et al. 2006). However, estimating metal fluxes exported to the coastal area (net fluxes) is more difficult, as it depends on the metal behaviour. Furthermore, the existing net flux estimates only take into account dissolved net fluxes of elements with conservative (e.g. U) or additive behaviour (e.g. Cd; Michel et al., 2000). In the case of a strictly conservative behaviour (U) the dissolved net fluxes are equivalent to the dissolved gross fluxes. From the gross fluxes calculated on the Garonne River at the upstream limit of tidal influence, we estimated annual $U$ net fluxes of $13.2 \mathrm{tyr}^{-1}$,

$15.5 \mathrm{t} \mathrm{yr}^{-1}, 6.5 \mathrm{t} \mathrm{yr}^{-1}, 8.0 \mathrm{t} \mathrm{yr}^{-1}$ and $8.2 \mathrm{t} \mathrm{yr}^{-1}$, respectively, in 2003, 2004, 2005, 2006 and 2007.

In the case of additive metal behaviour, flux estimates are based on an assumed conservative distribution in the 20-35 salinity range leading to a theoretical concentration at $S 1 / 40\left(\mathrm{C}_{0}\right)$. The net flux is then estimated from the following equation: $F_{\text {net }} 1 / 4 Q_{\mathrm{dwd}} x C_{0}$, with $Q_{\mathrm{dwd}}$ : daily water discharge at the instant $t$ and $C_{0}$ : theoretical concentration at salinity 0 (Boyle et al., 1974, 1982; Meybeck, 1992; Michel et al., 2000). Accordingly, $V_{D}$ daily net fluxes estimated from the different profiles ranged from $46 \mathrm{~kg}$ $\mathrm{d}^{-1}$ (July 2004) to $207 \mathrm{~kg} \mathrm{~d}^{-1}$ (March 2007). Although extrapolation to the annual timescale probably bears important uncertainty, the orders of magnitude of annual $V_{D}$ net fluxes were estimated from the relation between daily water discharges and daily net fluxes measured during the sampling campaigns (equation type potency, $y 1 / 465,447 x^{-0.565}, R^{1 / 4} 0.88$ ). The results obtained suggest that during the studied period, annual $V_{D}$ net fluxes were rather similar from one year to the other: $33.6 \mathrm{t} \mathrm{yr}^{-1}$ (2003), $36.7 \mathrm{t} \mathrm{yr}^{-1}$ (2004), $31.3 \mathrm{t} \mathrm{yr}^{-1}$ (2005), $32.3 \mathrm{t} \mathrm{yr}^{-1}$ (2006) and $33.5 \mathrm{t} \mathrm{yr}^{-1}$ (2007). In contrast, $\mathrm{Mo}_{\mathrm{D}}$ annual net fluxes were not estimated because of the variable behaviour of this element. However, we estimated daily net MoD fluxes from additive metal profiles (Fig. 6) to $150 \mathrm{~kg} \mathrm{~d}^{-1}$ and $200 \mathrm{~kg} \mathrm{~d}^{-1}$ for severe drought water discharges (September 2003) and low water discharge (July 2005) respectively. Those increasing daily net fluxes with low, increasing freshwater discharges ( $100 \mathrm{~m}^{3} \mathrm{~s}^{-1}$ ) reflect the relevance of sediment resuspension processes on the Gironde Estuary Mo ${ }_{D}$ balance.

\section{Conclusion}

The sampling strategy described in this paper pointed out the relevance of monitoring during contrasting water discharge situations in order to understand the variability of trace metal distribution. The acquisition of the present rare database on $U_{D}, V_{D}$ and MoD behaviour in estuarine environments allows distinguishing three different distribution patterns for these oxi-anions in the Gironde Estuary. Uranium showed a permanently conservative behaviour, whereas the apparent $V_{D}$ was more or less additive as a function of river water discharges, involving residence time and $\mathrm{V}_{\mathrm{D}}$ desorption from SPM in the MTZ. Molybdenum distribution was highly variable suggesting both additive and subtractive behaviours implying concurrent and/or reversible processes occurring simultaneously with different kinetics.

\section{Acknowledgements}

The authors thank the captains and the crews of the R.V. "Co^tes de la Manche" (INSU CIRMAT), M. Masson, S. Castelle and N. Girardot, C. Bossy, J.P. Lissalde and our Master students for their support during sampling and H. Derriennic and G. Lavaux for laboratory analyses. This study was supported by the Agence de l'Eau Adour/Garonne (DefiCadmium), the CG17, CG33, the 'Entente Lot' and the INSU CNRS EC2CO CYTRIX (VOTR'TRAM project).

\section{References}

Allen, G.P., Sauzay, G., Castaing, P., Jouanneau, J.M., 1977. Transport and deposition of suspended sediments in the Gironde Estuary, France. In: Wiley, M. (Ed.), Estuarine Processes. Academic Press, New York, pp. 63-81.

Audry, S., Blanc, G., Scha" fer, J., Chaillou, G., Robert, S., 2006. Early diagenesis of trace metals ( $\mathrm{Cd}, \mathrm{Cu}, \mathrm{Co}, \mathrm{Ni}, \mathrm{U}, \mathrm{Mo}$, and $\mathrm{V}$ ) in the freshwater reaches of a macrotidal estuary. Geochimica et Cosmochimica Acta 70, 2264-2282.

Audry, S., Blanc, G., Scha"fer, J., Robert, S., 2007. Effect of estuarine sediment resuspension on early diagenesis, sulphide oxidation and dissolved molybdenum and uranium distribution in the Gironde Estuary, France. Chemical Geology 238, $149-167$

Auger, Y., Bodineau, L., Leclercq, S., Wartel, M., 1999. Some aspects of vanadium and chromium chemistry in the English Channel. Continental Shelf Research 19, 2003-2018.

Barnes, C.E., Cochran, J.K., 1993. Uranium geochemistry in estuarine sediments: controls on removal and release processes. Geochimica et Cosmochimica Acta 57, 555-569.

Bortels, H., 1930. Uber die Bedeutung des Molyda" ns fü $r$ stickstoffbindende Nostocaceen. Archeology. Microbiology 11, 155-186.

Boyle, E.A., Collier, R., Dangler, A.T., Edmond, J.M., Ng, A.C., Stallard, R.F., 1974. On the chemical mass-balance in estuaries. Geochimica et Cosmochimica Acta 38, 1719-1728.

Boyle, E.A., Huested, S.S., Grant, B., 1982. The chemical mass-balance of the Amazon plume. II. Copper, nickel and cadmium. Deep-Sea Research 29, 1355-1364.

Castaing, P., Jouanneau, J.M., 1979. Temps de résidence des eaux et des suspensions dans l'estuaire de la Gironde. Journal Recherche Oce' anographie IV, 41-52. Castaing, P., 1981. Le transfert al'oce' an des suspensions estuariennes. Cas de la Gironde. The'se d'e'tat Sciences Naturelles Universite' Bordeaux1, $530 \mathrm{pp}$.

Church, T.M., Sarin, M.M., Fleisher, M.Q., Ferdelman, T.G., 1996. Salt marshes: an important coastal sink for dissolved uranium. Geochimica et Cosmochimica Acta $60,3879-3887$

Collier, R.W., 1985. Molybdenum in the Northeast Pacific Ocean. Limnology and Oceanography $30,1351-1354$.

Coynel, A., Scha” fer, J., Dabrin, A., Girardot, N., Blanc, G., 2007. Groundwater contributions to metal transport in a small river affected by mining and smelting waste. Water Research 41,3420-3428.

Dalai, T.K., Nishimura, K., Nozaki, Y., 2005. Geochemistry of molybdenum in the Chao Phraya River Estuary, Thailand: Role of suboxic diagenesis and porewater transport. Chemical Geology 218, 189-202.

Deborde, J., Anschutz, P., Chaillou, G., Etcheber, H., Commarieu, M.-V., Lecroart, P., Abril, G., 2007. The dynamics of phosphorus in turbid estuarine systems: example of the Gironde Estuary (France). Limnology and Oceanography 52, 862-872.

Directive 2000/60/EC of the European parliament and of the council. Official Journal of the European Communities, 2000.

Elbaz-Poulichet, F., Holliger, P., Huang, W.W., Martin, J.M., 1984. Lead cycling in estuaries, illustrated by the Gironde Estuary, France. Nature 308, 409-414.

Elbaz-Poulichet, F., Seidel, J.L., Jézéquel, D., Metzger, E., Pre' vot, F., Simonucci, C., Sarazin, G., Viollier, E., Etcheber, H., Jouanneau, J.M., Weber, O., Radakovitch, O., 2005. Sedimentary record of redox-sensitive elements (U, Mn, Mo) in a transitory anoxic basin (the Thau lagoon, France). Marine Chemistry 95, 271-281.

Emerson, S.R., Huested, S.S., 1991. Ocean anoxia and the concentrations of molybdenum and vanadium in seawater. Marine Chemistry 34, 177-196.

Etcheber, H., Relexans, J.C., Beliard, M., Weber, O., Buscail, R., Heussner, S., 1999. Distribution and quality of sedimentary organic matter on the Aquitanian margin (Bay of Biscay). Deep-Sea Research Part II: Topical Studies in Oceanography 46, 2249-2288.

Fogg, G.E., Wolfe, M., 1954. Nitrogen metabolism of blue green algae. Symposium Society for General Microbiology 4, 99-125

French National Mussel Watch programme RNO, Ifremer, Bulletin 2006. <http:// wwz.ifremer.fr/envlit/documents/bulletins/rno>.

Froelich, P.N., Klinkhammer, G.P., Bender, M.L., Luedtke, N.A., Heath, G.R., Cullen, D., Dauphin, P., Hammond, D., Hartman, B., Maynard, V., 1979. Early oxidation of organic matter in pelagic sediments of the eastern equatorial Atlantic: suboxic diagenesis. Geochimica et Cosmochimica Acta 43, 1075-1090.

Goldberg, S., Forster, H.S., Godfrey, C.L., 1996. Molybdenum adsorption on oxides, clay minerals and soils. Soil Science Society of America Journal 60, 425-432.

Goldberg, S., Forster, H.S., 1998. Factors affecting molybdenum adsorption by soils and minerals. Soil Sciences 163, 109-114. 
Goldberg, S., Lesch, S.M., Suarez, D.L., 2002. Predicting molybdenum adsorption by soils using soil chemical parameters in the Constant Capacitance Model. Soil Science Society of America Journal 66, 1836-1842.

Hayes, M.O., 1975. Morphology of sand accumulation in estuary: an introduction to the symposium. In: Cronin, L.E. (Ed.), Estuarine Research, vol. II. Academy Press, New York, pp. 3-22.

Head, P.C., Burton, J.D., 1970. Molybdenum in some ocean and estuarine waters. Journal of the Marine Biological Association of the United Kingdom 50, 439448

Howarth, R.W., Cole, J.J., 1985. Molybdenum availability, nitrogen limitation, and phytoplankton growth in natural waters. Science 229, 653-655.

Irigoien, X., Castel, J., 1997. Light limitation and distribution of chlorophyll pigments in a highly turbid estuary: the Gironde (SW France). Estuarine, Coastal and Shelf Science 44, 507-517.

Jandhyala, B.S., Hom, G.J., 1983. Physiological and pharmacological properties of vanadium. Life Sciences 33, 1325-1340

Jones, G.B., 1975. Molybdenum in a nearshore and estuarine environment, North Wales. Estuarine and Coastal Marine Science 2, 185-189.

Jouanneau, J.M., Latouche, C., 1981. The Gironde Estuary. In: Fü rchtbauer, H., Lisitzyn, A.P., Millerman, J.D., Seibold, E. (Eds.), Contribution to Sedimentology. Schweizerbart, E, Stuttgart, pp. 1-115

Jouanneau, J.M., Etcheber, H., Latouche, C., 1983. Impoverishment and decrease of metallic elements associated with suspended matter in the Gironde Estuary. NATO Conference Series, 4. Marine Sciences 9, 245-263.

Kingston, H.M., Barnes, I.L., Brady, T.J., Rains, T., 1978. Separation of eight transition elements from alkali and alkaline earth elements in estuarine and seawate with chelating resin and their determination by graphite furnace atomic absorption spectrometry. Analytical Chemistry 50, 64-70.

Kraepiel, A.M.L., Chiffoleau, J.F., Martin, J.M., Morel, F.M.M., 1997. Geochemistry of trace metals in the Gironde Estuary. Geochimica et Cosmochimica Acta 61, 1421-1436.

Ku, T.L., Knauss, K.G., Mathieu, G.G., 1977. Uranium in open ocean: concentration and isotopic composition. Deep-Sea Research 24, 1005-1017.

Li, Y.H., Chan, L.-H., 1979. Desorption of Ba and 226Ra from river-borne sediments in the Hudson Estuary. Earth Planetary Science Letters 43, 343-350.

Manheim, F.T., Landergren, S., 1978. Molybdenum. Handbook of Geochemistry. V. II/ 5, Sections 42 B-O. Springer-Verlag, Berlin.

Marino, R., Howarth, R.W., Chan, F., Cole, J.J., Likens, G.E., 2003. Sulfate inhibition of molybdenum-dependent nitrogen fixation by planktonic cyanobacteria under seawater conditions: A non-reversible effect. Hydrobiologia 500, 277-293.

Masson, M., 2007. Sources et transferts mé talliques dans le bassin versant de la Gironde. Ré activite' et mé canismes gé ochimiques dans l'estuaire fluvial de la Gironde, PhD thesis, Universite' Bordeaux1, 366 pp.

Masson, M., Blanc, G., Scha" fer, J., 2006. Geochemical signals and source contributions to heavy metal $(\mathrm{Cd}, \mathrm{Zn}, \mathrm{Pb}, \mathrm{Cu}$ ) fluxes into the Gironde Estuary via its major tributaries. Science of the Total Environment 370, 133-146.

Meybeck, M., 1992. Etablissement des flux polluants. Rapport inter-agences. Agence de l'eau. December 1992.

Michel, P., Boutier, B., Chiffoleau, J.F., 2000. Net fluxes of dissolved arsenic, cadmium, copper, zinc nitrogen and phosphorus from the Gironde Estuary (France): seasonal variations and trends. Estuarine, Coastal and Shelf Science 51, $451-462$.

Morris, A.W., 1975. Dissolved molybdenum and vanadium in the northeast Atlantic Ocean. Deep-Sea Research and Oceanographic Abstracts 22, 49-54.

Murphy, J., Riley, J.P., 1962. A modified single solution method for the determination of phosphate in natural waters. Analytica Chimica Acta 27, 31-36.

Osmond, J.K., Ivanovich, M., 1992. Uranium-series mobilization and surface hydrology. In: Ivanovich, M., Harmon, R.S. (Eds.), Uranium Series Disequilibrium, second ed., pp. 259-289.

Patterson, C.C., Settle, D.M., 1976. The reduction of orders of magnitude errors in lead analyses of biological materials and natural waters by evaluating and controlling the extent and sources of industrial lead contamination introduced during sample collecting, handling, and analysis. National Bureau of Standards Special Publication 422, 321-351.
Robert, S., 2003. Bilan ge' ochimique des é lé ments traces me' talliques dans l'estuaire de la Gironde. Re' activite' interne et anthropisation. PhD thesis, Institut National Polytechnique de Toulouse, Toulouse, $342 \mathrm{pp}$.

Robert, S., Blanc, G., Scha“ fer, J., Lavaux, G., Abril, G., 2004. Metal mobilization in the Gironde Estuary (France): the role of the soft mud layer in the maximum turbidity zone. Marine Chemistry $87,1-13$

Saari, H.K., Schmidt, S., Huguet, S., Lanoux, A., 2008. Spatio temporal variation of dissolved ${ }^{238} \mathrm{U}$ in the Gironde fluvial estuarine system (France). Journal of Environmental Radioactivity 99, 426-435.

Sadiq, M., 1988. Thermodynamic solubility relationships of inorganic vanadium in the marine environment. Marine Chemistry 23, 87-96.

Sarin, M.M., Church, T.M., 1994. Behaviour of uranium during mixing in the Delaware and Chesapeake estuaries. Estuarine, Coastal and Shelf Science 39, 619631.

Scha“ fer, J., Blanc, G., Lapaquellerie, Y., Maillet, N., Maneux, E., Etcheber, H., 2002. Ten year observation of the Gironde tributary fluvial system: fluxes of suspended matter, particulate organic carbon and cad mium. Marine Chemistry 79, 229-242. Shaw, T.J., Sholkovitz, E.R., Klinkhammer, G., 1994. Redox dynamics in the Chesapeake Bay: the effect on sediment/water uranium exchange. Geochimica et Cosmochimica Acta 58, 2985-2995.

Shiller, A.M., Mao, L., 1999. Dissolved vanadium on the Louisiana Shelf: effect of oxygen depletion. Continental Shelf Research 19, 1007-1020.

Shimmield, G.B., Price, N.B., 1986. The behaviour of molybdenum and manganese during early sediment diagenesis offshore Baja California, Mexico. Marine Chemistry 19, 261-280.

Smedley, P.L., Nicolli, H.B., Macdonald, D.M.J., Barros, A.J., Tullio, J.O., 2002. Hydrogeochemistry of arsenic and other inorganic constituents in groundwaters from La Pampa, Argentina. Applied Geochemistry 17, 259-284.

Smith, K.J., Organo, C., Leon Vintro, L., Mitchell, P.I., 2001. Evidence for the non conservative behaviour of uranium in the Gironde Estuary (France) during low river discharge. In: d'Elbe'e, J., Prouzet, P. (Eds.), Oceanographie du Golfe de Gascogne, Actes de Colloques 31, VIIth International Colloquium on the Oceanography of the Biscay Gulf, 4-6 April 2000. Editions Ifremer, Biarritz, pp. 297-302.

Sottolichio, A., Castaing, P., 1999. A synthesis on seasonal dynamics of highlyconcentrated structures in the Gironde Estuary. Comptes Rendus de l'Acade' mie de Sciences - Serie IIa: Sciences de la Terre et des Plane` tes 329, 795-800.

Swarzenski, P.W., McKee, B.A., Booth, J.G., 1995. Uranium geochemistry on the Amazon Shelf: chemical phase partitioning and cycling across a salinity gradient. Geochimica et Cosmochimica Acta 59, 7-18.

Toole, J., Baxter, M.S., Thomson, J., 1987. The behaviour of uranium isotopes with salinity change in three UK estuaries. Estuarine, Coastal and Shelf Science 25 283-297.

Tribovillard, N., Lyons, T.W., Riboulleau, A., Bout-Roumazeilles, V., 2008. A possible capture of molybdenum during early diagenesis of dysoxic sediments. Bulletin Socie' té Gé ol ogique de France 179, 3-12.

Van Den Berg, C.M.G., Khan, S.H., Daly, P.J., Riley, J.P., Turner, D.R., 1991. An electrochemical study of $\mathrm{Ni}, \mathrm{Sb}, \mathrm{Se}, \mathrm{Sn}, \mathrm{U}$ and $\mathrm{V}$ in the estuary of the Tamar. Estu arine, Coastal and Shelf Science 33, 309-322.

Van der Sloot, H.A., Hoede, D., Wijkstra, J., 1985. Anionic species of V, As, Se, Mo, Sb, Te and $W$ in the Scheldt and Rhine estuaries and the Southern Bight (North Sea). Estuarine, Coastal and Shelf Science 21, 633-651.

Van der Weijden, C.H., Middelburg, J.J., De Lange, G.J., Van der Sloot, H.A., Hoede, D., Woittiez, J.R.W., 1990. Profiles of the redox-sensitive trace elements As, Sb, V, $\mathrm{Mo}$ and $\mathrm{U}$ in the Tyro and Bannock Basins (eastern Mediterranean). Marine Chemistry $31,171-186$.

Wedepohl, K.H., 1978. Molybdenum 42. Handbook of Geochemistry, vol. II-2. Springer Verlag, Heidelberg.

Wehrli, B., Stumm, W., 1989. Vanadyl in natural waters: adsorption and hydrolysis promote oxygenation. Geochimica et Cosmochimica Acta 53, 69-77.

Windom, H., Smith, R., Niencheski, F., Alexander, C., 2000. Uranium in rivers and estuaries of globally diverse smaller watersheds. Marine Chemistry 68, 307-321.

Zheng, Y., Anderson, R.F., van Geen, A., Kuwabara, J., 2000. Authigenic molybdenum formation in marine sediments: a link to pore water sulfide in the Santa Barbara Basin. Geochimica et Cosmochimica Acta 64, 4165-4178. 